Artikel Penelitian

\title{
Pengaruh Pengetahuan Dan Sikap Orang tua Tentang Kesehatan Reproduksi Remaja Terhadap Pernikahan Dini Di Kecamatan Trowulan Kabupaten Mojokerto
}

\section{Rina Widiyawati, Siti Muthoharoh}

Prodi Ilmu Keperawatan STIKES Dian Husada J1. Raya Gemekan No. 77 Sooko Mojokerto Email: gugik.rina@gmail.com, Telepon: 082330233064

\begin{abstract}
Abstrak: Menurut United Nations Development Economic and Social Affairs Indonesia merupakan negara ke-37 di dunia dan peringkat ke-2 di ASEAN setelah Kamboja sebagai negara dengan presentase pernikahan usia muda yang tinggi. Organisasi Kesehatan Dunia WHO mengharapkan Indonesia lebih komitmen menurunkan angka kematian ibu dan bayi sebagai dampak pernikahan dini. Tujuan dari penelitian ini adalah mengetahui pengaruh pengetahuan dan sikap orangtua tentang kesehatan reproduksi remaja terhadap kejadian pernikahan dini di Kecamatan Trowulan Kabupaten Mojokerto. Penelitian ini menggunakan metode deskriptif analitik dengan desain cross sectional. Variabel independen adalah pengetahuan dan sikap orangtua tentang kesehatan reproduksi, variabel dependen adalah kejadian pernikahan dini. Populasi dalam penelitian ini adalah orangtua yang memiliki anak perempuan yang telah menikah dan jumlah sampel sebanyak 100 orang dengan teknik pengambilan sampel menggunakan purposive sampling. Pengambilan data dengan menggunakan kuesioner tertutup dan dianalisa menggunakan Uji Regresi Logistik. Terdapat pengaruh pengetahuan orangtua tentang kesehatan reproduksi remaja terhadap kejadian pernikahan dini dengan $p$-value $=0.03$ dan terdapat pengaruh sikap orangtua tentang kesehatan reproduksi remaja tentang kejadian pernikahan dini dengan $p$-value $=$ 0.00. Kedua variabel independen memiliki pengaruh terbalik dengan kejadian pernikahan dini, semakin tinggi pengetahuan dan semakin positif sikap tentang kesehatan reproduksi remaja maka semakin menurun kejadian pernikahan dini di Kecamatan Trowulan Kabupaten Mojokerto.
\end{abstract}

Kata kunci: Kesehatan Reproduksi Remaja, pengetahuan, sikap, pernikahan dini,

Abstact: According to United Nations DevelopmentEconomic and Social Affairs, Indonesia is $37^{\text {th }}$ country in the world and $2^{\text {nd }}$ in Southeast Asia aafter Cambodia with high percentage of early marriage. World Helath Organizatioon expects Indonesia government to be more commited to decrease maternal and infant mortality rates as the impacts of early marriage. This study aimed to discover The InfluenceOf Knowledge and Attitude of Adolescence Reproduction Health on Early Marriage in Trowulan Subdistrict Mojokerto Regency.This was an analytic descriptive study and cross-sectional design. The indepenndent variables were knowledge and attitude of adolescence reproduction health and dependent variable was early marriage.The study population was all the parents who had daughter which had marriage totalling 100 people.Data were collected by closed questionnaire and subsequently tested using logistic regression test.There is an influence of parental knowledge of adolescent reproductive health on the early marriage with $p$-value $=0.03$ and there is an influence of parental attitude of adolescent reproductive health on the early marriagewit $p$-value $=0.00$. 


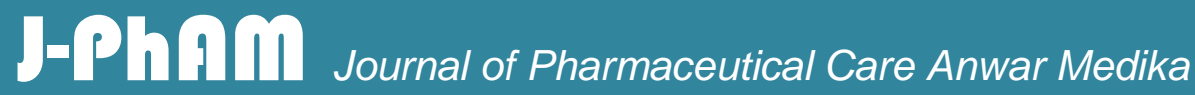

\section{Artikel Penelitian}

Both of independent variables had reverse effect of early marriage, higher the knowledge and more positive the attitude of adolescent reproduction health so lower the accident early marriage in Trowulan Subdistrict Mojokerto Regency.

Keyword: Adolescent reproduction health, knowledge, attitude, early marriage.

\section{PENDAHULUAN}

Menghilangkan segala bentuk praktik berbahaya, seperti pernikahan anak-anak, usia anak/dini dan terpaksa serta sunat perempuan adalah salah satu target akses kesehatan reproduksi. ${ }^{11}$ Sekretaris Jenderal Perserikatan Bangsa-Bangsa (PBB) menghimbau adanya target penting dalam Tujuan Pembangunan Berkelanjutan pasca 2015 yaitu menghilangkan perkawinan anak atau perkawinan dini. Indonesia beserta 116 negara lainnya sangat mendukung himbauan Sekretaris Jenderal PBB tersebut. ${ }^{8}$

Menurut United Nations Development Economic and Social Affairs Indonesia merupakan negara ke-37 di dunia dan peringkat ke-2 di ASEAN setelah Kamboja sebagai negara dengan presentase pernikahan usia muda yang tinggi. ${ }^{10}$ Menurut data BPS tahun 2015, terdapat $31.72 \%$ perempuan menikah rentang umur 16-18 tahun dan sebesar 7.96 persen perempuan menikah rentang umur 25-30 tahun. ${ }^{8}$

Masa reproduksi wanita salah satunya dipengaruhi oleh usia kawin pertama. Hal ini berkaitan erat dengan jumlah kepadatan penduduk sebuah negara. Wanita yang memiliki usia kawin pertama rendah, atau semakin muda usia kawin wanita, maka akan semakin lama pula masa reproduksi wanita. Target TFR di Indonesia pada tahun 2015 adalah 2.1 dan Provinsi Jawa Timur sendiri diperkirakan akan memiliki nilai TFR yang cenderung semakin menurun yaitu dari 2.012 pada tahun 2012 menjadi 1.946 pada tahun $2017 .{ }^{4}$ Kabupaten Mojokerto memiliki angka TFR sebesar 1.9 dan tercatat 26 ibu yang berusia 1519 melahirkan. $^{7}$

Indonesia mengalami penurunan jumlah perempuan yang menikah dengan usia di bawah umur 17 tahun yaitu 31.82 pada tahun 2009 menjadi 26.33 pada tahun 2013. 


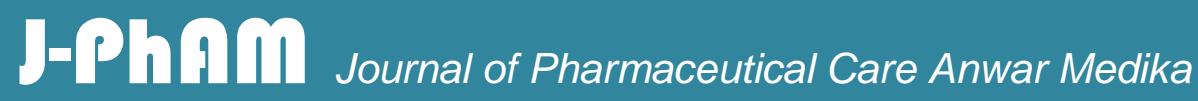

\section{Artikel Penelitian}

Jumlah perempuan yang menikah di bawah umur 17 tahun di Kabupaten Mojokerto masih fluktuatif atau prosentasenya naik turun. Tahun 2009 jumlah perempuan menikah di bawah 17 tahun sebesar $25.14 \%$, kemudian turun menjadi $24.31 \%$ ditahun 2010 , kemudian turun lagi menjadi 18.89\% pada tahun 2011, kemudian pada tahun 2012 mengalami kenaikan menjadi $20.49 \%$ dan meningkat lagi menjadi $21.34 \%$ di tahun $2013 .^{3}$

Indonesia diharapkan untuk dapat lebih aktif lagi dalam menurunkan angka kematian ibu dan bayidan hal ini telah disampaikan oleh Organisasi Kesehatan Dunia WHO kepada Indonesia. Walaupun secara signifikan Indonesia telah mengalami penurunan jumlah angka kematian ibu dan bayi yaitu sebesar 72\%, akan tetapi kawasan ASEAN masih memiliki negara-negara yang memiliki risiko tinggi angka kematian ibu dan bayi akibat dari wanita menikah muda, salah satunya adalah Negara Indonesia.Risiko tinggi kematian ibu dan bayi ini tidak lepas dari meningkatnya jumlah wanita yang menikah dibawah usia 20 tahun atau menikah dini. ${ }^{1}$

Berbagai risiko kehamilan dan persalinan menyertai wanita yang hamil pada usia remaja. Kejadian aborsi, pre eklamsia, eklamsia, anemia, infeksi, kanker rahim maupun kematian bayiadalah risiko tinggi yang terjadi pada saat kehamilan di usia remaja. Bayi premature, BBLR, kesulitan persalinan, kematian bayi dan kelainan bawaan merupakan risiko kelahiran yang banyak terjadi pada remaja wanita yang melahirkan. ${ }^{6}$ Pada kabupaten Mojokerto penyebab kematian bayi diakibatkan oleh BBLR (berat badan lahir rendah), asfiksia, congenital, infeksi dan lain-lain. Walaupun terjadi penurunan angka kematian bayi tahun 2014 namun tidak signifikan jika dibandingkan tahun 2013 yaitu dari 129 menjadi 127 anak per 1000 kelahiran hidup $(\mathrm{KH}){ }^{9}$

Angka Kematian Ibu (AKI) yang disebabkan pernikahan di usia remaja masih tergolong tinggi di Indonesia dandibandingkan dengan negara tetangga, AKI di Indonesia masih lebih tinggi. Kematian ibu diantaranya karena faktor 3T (terlambat mengambil keputusan, mendapatkan transportasi dan penanganan di sarana pelayanan kesehatan) serta 4T (terlalu tua, muda, banyak dan dekat jarak kehamilannya). ${ }^{9}$ 


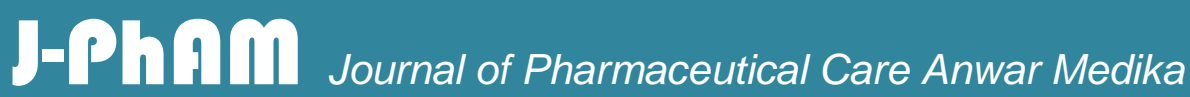

\section{Artikel Penelitian}

Faktor sosio demografi, faktor budaya dan nilai virginitas adalah faktor penyebab terjadinya pernikahan dini ${ }^{5}$ serta akibat pergaulan masa remaja. ${ }^{18}$ Penelitian yang dilakukan oleh BKKBN di Kalimantan Selatan, Bangka Belitung, Sulawesi Tengah dan Jawa Barat diperoleh hasil faktor utama terjadinya pernikahan dini adalah meningkatnya gejala modernisasi, rendahnya minat masyarakat atas pendidikan, faktor ekonomi dan kemiskinan, budaya, peran adat dan agama, peran orangtua sebagai pengambil keputusan dan lemahnya koordinasi dan perencanaan kebijakan Pemerintah dalam pengendalian pernikahan dini.

Tujuan penelitian dari penelitian ini adalah menganalisis pengaruh pengetahuan dan sikap orangtua tentang kesehatan reproduksi remaja terhadap kejadian pernikahan dini di Kecamatan Trowulan Kabupaten Mojokerto dan diharapkan penelitian ini dapat memberikan informasi terkait pentingnya pengetahuan dan sikap orangtua tentang kesehatan reproduksi remaja dalam kejadian pernikahan dini, sehingga orangtua dapat dijadikan sebagai sasaran pendidikan kesehatan juga dalam Program Pendewasaan Usia Perkawinan.

\section{BAHAN DAN METODE}

Populasi terjangkau penelitian ini adalah seluruh orangtua yang memiliki anak perempuan yang menikah pertama yaitu 552 orang, berdomisili di Kecamatan Trowulan dan tercatat dalam Kantor Urusan Agama Kecamatan Trowulan Kabupaten Mojokerto tahun 2017. Penelitian dilaksanakan pada bulan Pebruari - April 2018 dengan teknik pengambilan sampel menggunakan purposive sampling dan diperoleh responden sebanyak 100 orang. Variabel independen dalam penelitian ini adalah pengetahuan dan sikap orangtua tentang kesehatan reproduksi remaja, dan variabel dependennya adalah kejadian pernikahan dini di Kecamatan Trowulan Kabupaten Mojokerto. Penelitian ini adalah penelitian analitik deskriptif dengan menggunakan desain cross sectional. Instrumen yang digunakan adalah kuesioner tertutup dan data hasil penelitian dianalisis menggunakan Uji Regresi Logistik. 


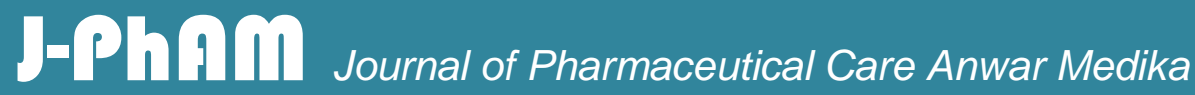

\section{Artikel Penelitian}

\section{HASIL}

Tabel 1 menunjukkan sebaran frekuensi karakteristik responden. Responden dalam penelitian ini adalah orangtua yang memiliki anak perempuan menikah pertama di tahun 2017 dan berdomisili di Kecamatan Trowulan Kabupaten Mojokerto sebanyak 100 responden. Berdasarkan umur responden lebih dari separuh berusia 40 - 60 tahun (68\%), berjenis kelamin perempuan (72\%), sebagian besar berpendidikan terakhir SMP (36\%), bekerja sebagai petani (39\%) dan hampir seluruhnya berpenghasilan dibawah UMR Kabupaten Mojokerto (94\%).

\section{Tabel 1. Sebaran Frekuensi Karakteristik Responden}

\begin{tabular}{|l|c|c|}
\hline \multicolumn{1}{|c|}{ Karakteristik Responden } & $\Sigma$ & $\%$ \\
\hline Umur & & \\
$18-40$ tahun & 22 & 22 \\
$40-60$ tahun & 68 & 68 \\
$>60$ tahun & 10 & 10 \\
\hline Total & 100 & 100 \\
\hline Jenis Kelamin & & \\
Laki-laki & 28 & 28 \\
Perempuan & 72 & 72 \\
\hline Total & 100 & 100 \\
\hline Pendidikan Terakhir & & \\
Tidak sekolah & 7 & 7 \\
SD & 14 & 14 \\
SLTP & 36 & 36 \\
SLTA & 34 & 34 \\
Perguruan Tinggi & 9 & 9 \\
\hline Total & 100 & 100 \\
\hline Pekerjaan & & \\
PNS & 2 & 2 \\
Swasta & 23 & 23 \\
Wiraswasta & 36 & 36 \\
Petani & 39 & 39 \\
\hline Total & 100 & 100 \\
\hline Pendapatan & & \\
< UMR & 94 & 94 \\
Z UMR & 6 & 6 \\
\hline Total & 100 & 100 \\
\hline
\end{tabular}

Sumber: Data Primer, 2018 


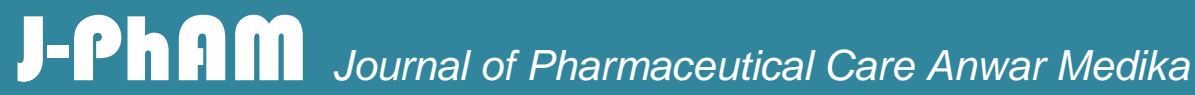

\section{Artikel Penelitian}

Tabel 2 menunjukkan sebaran frekuensi pengetahuan dan sikap responden tentang kesehatan reproduksi berdasarkan kejadian pernikahan dini. Berdasarkan hasil penelitian, diperoleh data bahwa orangtua yang memiliki anak perempuan menikah dini (menikah pertama diusia $\leq 20$ tahun) sebanyak 44 responden (44\%) dan yang tidak menikah dini (menikah pertama usia > 20 tahun) sebanyak 56 responden $(56 \%)$. Hasil penelitian menunjukkan bahwa sebagian besar responden memiliki tingkat pengetahuan tentang kesehatan reproduksi remaja kategori cukup, baik pada kejadian pernikahan dini maupun tidak masing-masing sebesar 32 responden (72\%) dan 40 responden (67\%). Pada hasil penelitian variabel sikap orangtua tentang kesehatan reproduksi remaja, diperoleh hasil bahwa sebagian besar responden memiliki sikap negatif pada kelompok terjadinya pernikahan dini sebesar 30 orang $(68 \%)$ dan sebagian besar responden memiliki sikap positif pada kelompok tidak terjadi pernikahan dini sebesar 46 orang (72\%).

Tabel 2. Sebaran Frekuensi Pengetahuan dan Sikap Responden tentang Kesehatan Reproduksi Berdasarkan Kejadian Pernikahan Dini

\begin{tabular}{|c|c|c|c|c|c|c|c|c|c|}
\hline \multirow{3}{*}{ Variabel } & \multicolumn{4}{|c|}{ Kejadian Pernikahan Dini } & & & \multirow{3}{*}{$p$-value } & \multirow{3}{*}{ B } & \multirow{3}{*}{$\operatorname{Exp}(\mathrm{B})$} \\
\hline & \multicolumn{2}{|c|}{$\begin{array}{c}\text { Iya } \\
\text { (menikah } \\
\leq 20 \text { tahun) }\end{array}$} & \multicolumn{2}{|c|}{$\begin{array}{c}\text { Tidak } \\
\text { (menikah } \\
>20 \text { tahun) }\end{array}$} & \multicolumn{2}{|c|}{ Total } & & & \\
\hline & $\Sigma$ & $\%$ & $\Sigma$ & $\%$ & $\Sigma$ & $\%$ & & & \\
\hline \multicolumn{10}{|l|}{ Pengetahuan } \\
\hline Kurang & 7 & 16 & 6 & 11 & 13 & 13 & & & \\
\hline Cukup & 32 & 73 & 40 & 67 & 72 & 72 & 0.03 & -1.077 & .341 \\
\hline Baik & 5 & 11 & 10 & 22 & 15 & 15 & & & \\
\hline Total & 44 & 100 & 56 & 100 & 100 & 100 & & & \\
\hline \multicolumn{10}{|l|}{ Sikap } \\
\hline Negatif & 30 & 68 & 10 & 28 & 40 & 40 & 0.00 & -3.024 & .049 \\
\hline Positif & 14 & 32 & 46 & 72 & 60 & 60 & & & \\
\hline Total & 44 & 100 & 56 & 100 & 100 & 100 & & & \\
\hline
\end{tabular}

Hasil peneltian selanjutnya dilakukan analisis regresi logistik dan diperoleh hasil variabel pengetahuan orangtua tentang kesehatan reproduksi remaja dan sikap orangtua tentang kesehatan remaja memiliki nilai nilai $p$-value $<0.05$ yaitu masing-masing sebesar 


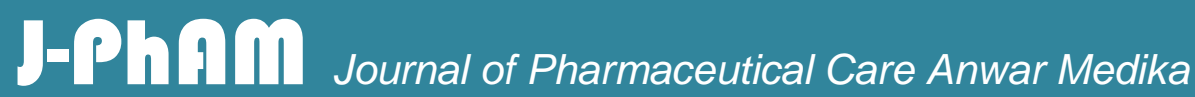

\section{Artikel Penelitian}

0.03 dan 0.00. Hal ini membuktikkan bahwa pengetahuan dan sikap orangtua tentang kesehatan reproduksi remaja mempengaruhi kejadian pernikahan dini di Kecamatan Trowulan Kabupaten Mojokerto. Hasil uji regresi logistik juga menjelaskan bahwa terdapat hubungan terbalik dari variabel pengetahuan dan sikap terhadap kejadian pernikahan dini. Pengetahuan orangtua tentang kesehatan reproduksi dan sikap orangtua tentang kesehatan reproduksi remaja berpengaruh terbalik dengan kejadian pernikahan dini dengan nilai B masing-masing sebesar -1.077 dan -3.024 , sehingga semakin tinggi pengetahuan dan semakin positif sikap orangtua tentang kesehatan reproduksi remaja maka akan semakin menurun angka kejadian pernikahan dini.

Nilai $\exp (\mathrm{B} 1)$ sebesar 0.341 menunjukkan bahwa peningkatan pengetahuan sebesar 1 akan ada perubahan sebesar 0.341 pada terjadinya pernikahan dini. Dengan demikian bahwa jika ada peningkatan pengetahuan ibu dari kurang ke baik akan menurunkan probabilitas kejadian pernikahan dini sebesar 0.341 kali. Nilai exp(B2) sebesar 0.049 menunjukkan bahwa peningkatan sikap sebesar 1 akan ada perubahan sebesar 0.049 pada terjadinya pernikahan dini. Dengan demikian bahwa jika ada peningkatan sikap orangtua dari negatif ke positif akan menurunkan probabilitas kejadian pernikahan dini sebesar 0.049 kali.

\section{PEMBAHASAN}

Sebagian besar responden sebanyak 68 responden (68\%) berada pada usia rentang 40 - 60 tahun. Seseorang yang berada pada usia 40 - 60 tahun dapat dikategorikan sebagai usia madya atau orang paruh baya yang sudah memiliki kematangan fisik maupun psikis. Seseorang yang berada pada usia madya sudah dapat berpikir dan memutuskan segala sesuatu hal dengan bijaksana dan matang. ${ }^{17}$ Responden dalam penelitian ini sebagai orangtua tentunya merasa sudah mampu mengambil keputusan dan merasa sudah bijaksana dalam memutuskan menikahkan anaknya atau tidak pada anak usia $\leq 20$ tahun atau memutuskan terjadinya pernikahan dini atau tidak.

Sebagian besar responden berjenis kelamin perempuan sebanyak 72 responden (72\%). Di Indonesia menganut sistem patriarkhi yaitu kebudayaan yang menekankan pada 


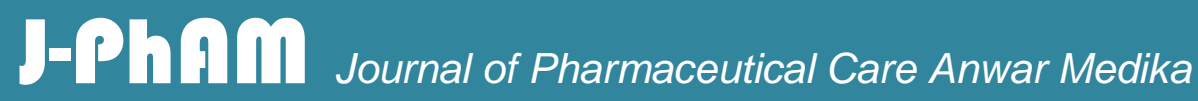

\section{Artikel Penelitian}

orang laki-laki sebagai pemegang kendali atau kekuasaan atas kehidupan sosial dan ekonomi sebuah rumah tangga ${ }^{14}$ Namun dalam penelitian ini responden sebagian besar adalah ibu dikarenakan suami pada saat itu sedang tidak ada dirumah atau bekerja. Meskipun demikian responden mengatakan bahwa segala keputusan terjadinya pernikahan dini atau tidak tetap atas keputusan suami sebagai kepala rumahtangga.

Pendidikan terakhir responden paling banyak adalah pendidikan SLTP yaitu 36 orang (36\%) namun beberapa juga berpendidikan terakhir SMA sebanyak 23 orang (34\%). Tingkat pendidikan orangtua mempengaruhi persepsi orangtua tentang persepsi manfaat dan persepsi hambatan tentang pernikahan dini. ${ }^{13}$ Persepsi manfaat atau persepsi hambatan tentang pernikahan dini responden tentunya juga dibentuk dari faktor lingkungan salah satunya adalah sumber informasi.

Pekerjaan responden sebanyak 39 orang (39\%) adalah petani dan sebanyak 36 orang (36\%) adalah wiraswasta atau sebagai buruh pembuatan arca dan sepatu. Orangtua yang bekerja memungkinkan untuk dapat memperoleh informasi kesehatan lebih banyak misalkan dari lingkungan, teman tempat bekerja dan memungkinkan mendapatkan pengalaman lebih banyak dibandingkan orangtua tidak bekerja. Pendapatan responden hampir seluruhnya di bawah UMR Kabupaten Mojokerto yaitu sebanyak 94 orang (94\%). Faktor ekonomi orangtua ikut mempengaruhi orangtua dalam mengambil keputusan menikahkan dini putrinya, dengan harapan setelah menikah dapat meringankan beban keluarga. ${ }^{15}$

Hasil penelitian menunjukkan bahwa terdapat pengaruh pengetahuan dan sikap orangtua tentang kesehatan reproduksi terhadap kejadian pernikahan dini di Kecamatan Trowulan Kabupaten Mojokerto. Sebagian besar tingkat pengetahuan orangtua tentang kesehatan reproduksi remaja kategori sedang baik pada kelompok menikah dini maupun tidak menikah dini. Salah satu bentuk dukungan orangtua adalah dukungan informasional. Orangtua dapat mentransfer pengetahuan atau informasi yang mereka peroleh tentang kesehatan reproduksi remaja kepada putrinya. ${ }^{16}$ Selain dukungan orangtua, terjadinya pernikahan di usia muda atau tidak juga dipengaruhi oleh faktor ekonomi dan sosial. ${ }^{12}$ 


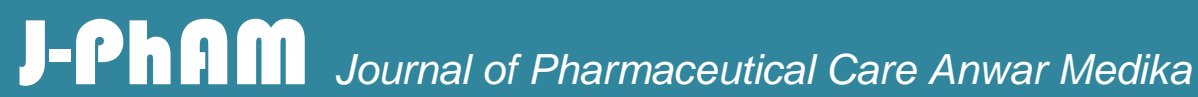

\section{Artikel Penelitian}

Hasil penelitian menunjukkan bahwa responden sebagian besar kurang mengetahui hak reproduksi remaja dan program pendewasaan usia perkawinan.

Penelitian juga menunjukkan hasil bahwa masih terdapat pengetahuan orangtua tentang kesehatan reproduksi remaja yang tinggi pada kelompok terjadinya pernkahan dini. Hal ini kemungkinan disebabkanmeskipun orangtua memiliki pengetahuan yang baik namun tidak menyampaikan informasi tersebut karena menganggap informasi kesehatan reproduksi adalah tugas tenaga pendidikandan sekolah. Pada kelompok tidak terjadi pernikahan dinijuga masih terdapat pengetahuan orangtua tentang kesehatan reproduksi remaja kategori rendah. Hal ini kemungkinan disebabkan pengaruh faktor lingkungan yang positif, sehingga membantu responden membentuk sikap yang positif sehingga tidak terjadi pernikahan dini.

Dalam penelitian ini juga diperoleh hasil terdapat pengaruh sikap orangtua tentang kesehatan reproduksi remaja terhadap kejadian pernikahan dini di Kecamatan Trowulan Kabupaten Mojokerto. Lebih dari separuh responden yang memiliki sikap negatif memiliki anak perempuan yang menikah dini, begitu juga dengan sikap positif responden lebih dari separuh memiliki anak perempuan yang menikah dengan usia ideal (tidak menikah dini). Sikap dipengaruhi beberapa faktor yaitu pengalaman pribadi, pengetahuan, emosional dan media massa. Informasi yang diperoleh akan membentuk sebuah opini dan membentuk sebuah sikap, baik itu sikap negatif maupun sikap positif. ${ }^{2}$ Dalam penelitian ini dapat disimpulkan bahwa orangtua yang memiliki sikap negatif terhadap kesehatan reproduksi remaja mempengaruhi perilaku orangtua dalam mengambil keputusan menikahkan dini anak perempuannya.

\section{KESIMPULAN}

Dalam penelitian ini dapat disimpulkan bahwa terdapat pengaruh pengetahuan dan sikap orangtua tentang kesehatan reproduksi remaja dengan kejadian pernikahan dini di Kecamatan Trowulan Kabupaten Mojokerto. 


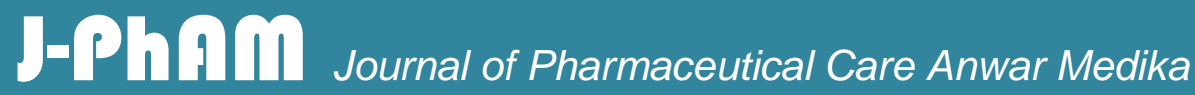

\section{Artikel Penelitian}

Terdapat hubungan terbalik antara pengetahuan dan sikap orangtua tentang kesehatan reproduksi remaja dengan kejadian remaja, yang berarti semakin tinggi pengetahuan dan semakin positif sikap orangtua tentang kesehatan reproduksi maka akan semakin menurunkan kejadian pernikahan dini. Dalam penelitian selanjutnya dapat diteliti variabel lainnya yang mempengaruhi pernikahan dini seperti faktor lingkungan atau budaya, faktor perilaku remaja, faktor persepsi remaja, atau faktor lainnya. Manfaat dari penelitian ini adalah orangtua juga dapat dijadikan sebagai sasaran pendidikan kesehatan reproduksi oleh BBKBN dan orangtua juga diberikan pendidikan mengenai teknik penyampaian informasi yang efektif khususnya kepada remaja.

\section{UCAPAN TERIMA KASIH}

Penulis sampaikan terimakasih kepada pihak-pihak yang telah membantu kelancaran dalam pelaksanaan penelitian ini. Terimakasih kepada Bapak Kepala Dinas Badan Pemberdayaan Perempuan dan Keluarga Berencana Kabupaten Mojokerto, Kepala Kementrian Agama Kabupaten Mojokerto, Kepala KUA Kecamatan Trowulan, Camat Trowulan, PLKB Kecamatan Trowulan dan Kader KB Kecamatan Trowulan.

\section{DAFTAR PUSTAKA}

1. ACDP Indonesia. WHO Minta Indonesia Kurangi Angka Pernikahan Dini [online artikel]. 2016. [Diakses 16 Nopember 2017]. Available at: https://acdpindonesia.wordpress.com/2016/09/06/who-minta-indonesia-kurangi-angka-pernikahan-dini/.

2. Azwar, Saifuddin. Sikap Manusia : Teori dan Pengukurannya. Yogyakarta: Pustaka Pelajar; 2009

3. Badan Pusat Statistik. nd. [Diakses 13 Oktober 2017]. Available at: www.jatim.bps.go.id/linkTabelStatus/View/id/160

4. Bappenas. Proyeksi Penduduk Indonesia 2010-2035. Jakarta: Badan Perencanaan Nasional. 2013. [Diakses 9 Nopember 2017]. Available at: www.bappenas.go.id/files/5413/9148/Proyeksi_Penduduk_Indonesia_2010_2035.pdf 


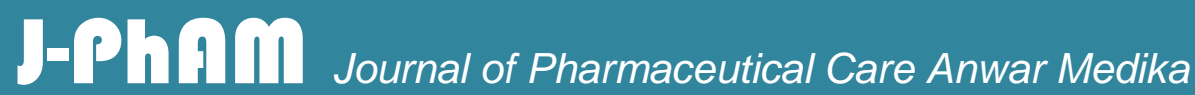

\section{Artikel Penelitian}

5. Birech J. Child Marriage: A Cultural Health Phenomenon. International Journal of Humanities and Social Science, 2013:3(17):97-103.

6. BKKBN. Pendewasaan Usia Perkawinan \& Hak-Hak Reproduksi bagi Remaja Indonesia. Jakarta: Badan Koordinasi Keluarga Berencana Nasional; 2010.

7. BKKBN. Penyajian Tentang TFR Kabupaten dan Kota: Data Susenas 2010. Jakarta: Badan Koordinasi Keluarga Berencana Nasional; 2013.

8. BPSa. Kemajuan yang Tertunda: Analisi Data Perkawinan Usia Anak di Indonesia. Jakarta: Badan Pusat Statistik; 2015.

9. Depkes. Profil Kesehatan Dinas Kesehatan Kabupaten Mojokerto Tahun 2014. 2015. [Diakses 9 Nopember 2017]. Available at: www.depkes.go.id/development/site/depkes/-

resources/download/profil/PROFIL_KAB_KOTA_2014/3516_jatim_kab_mojokerto 2014.pdf.

10. Jain et al. Early Marriage of Girls As A Barrier To Their Education. International Journal of Advanced Engineering Technology,2011:2(3):193-198

11. Kemenkes RI. Kesehatan Dalam Kerangka Sustainable Development Goals (SDGs). Jakarta: Kementrian Kesehatan Republik Indonesia; 2015. [Diakses 8 September 2017]. Available at: www.pusat2.litbang.dinkes.go.id/pusat2vi/wpcontent/uploads12015/12/SDGs-Ditjen-BGKIA.pdf

12. Qibtiyah M. Faktor Yang Mempengaruhi Perkawinan Muda Perempuan. Jurnal Biometrika dan Kependudukan, 2014:3(1):50-58.

13. Rosilayati, Pitoewas B \& Nurmalisa Y. Persepsi Orangtua Terhadap Pernikahan Dini Di Kelurahan Garuntang. 2013. [Diakses 2 Desember 2017]. Available at: http://download.portalgaruda.org/article.php?article=289021\&val=7237\&title=PERS EPSI\%20ORANG\%20TUA\%20TERHADAP\%20PERNIKAHAN\%20DINI\%20DI \%20KELURAHAN\%20GARUNTANG

14. Sakina dan Siti. Menyoroti Budaya Patriarki Di Indonesia.Social Work Jurnal, 2017:7(1):71-80

15. UNICEF. Early Marriage Child Spouses. Italy: United Nations Children's Fund; 2006. 


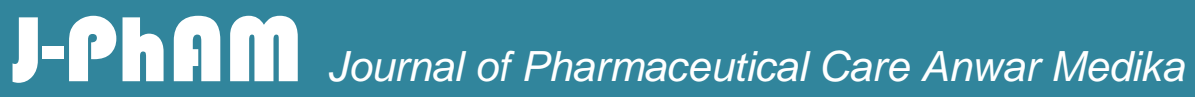

Artikel Penelitian

16. Utami TIW. Hubungan Pengetahuan dan Sikap Orang Tua Tentang Kesehatan Reproduksi Dengan Tindakan Orang Tua Mengawinkan Puterinya Di Usia Remaja (Studi di Kecamatan Sukowono Kabupaten Jember) [Skripsi]. Jember: Universitas Jember; 2013.

17. Wawan, A. dan Dewi, M. Teori dan Pengukuran Pengetahuan, Sikap dan Perilaku Manusia. Yogyakarta : Nuha Medika; 2010.

18. Zuraidah. Analisis Pencapaian Pendewasaan Usia Perkawinan Di Kecamatan Pancurbatu Kabupaten Deli Serdang Tahun 2015 [Tesis]. Medan: Universitas Sumatera Utara; 2015. 